\title{
Study of structural characteristics of vitrinites of Kuznetsk basin coals
}

\author{
(C) Anna N. Popova, ${ }^{*+}$ and Natalia I. Fedorova \\ Federal Research Center on Coal and Coal Chemistry. Siberian Branch of the Russian \\ Academy of Sciences. Sovetsky Ave., 18. Kemerovo, 650000.Russia.E-mail: h991@yandex.ru
}

\begin{abstract}
*Supervising author; ${ }^{+}$Corresponding author
Keywords: XRD analysis, crystal structure, turbostratic structure, structural parameters, coal vitrinites, stage of metamorphism.
\end{abstract}

\begin{abstract}
The article is devoted to research of the main structural parameters of vitrinites of bituminous coals of various metamorphism degrees carried out by methods of X-ray phase and X-ray structural analysis. Vitrinite concentrates were obtained from coal of the Kuznetsk Basin. The main X-ray structural parameters were estimated: the number of carbon atoms in the lamellae $\left(\mathrm{n}_{\mathrm{atc}}\right)$, the longitudinal size of the lamellae, and the height of their stacking ( $\mathrm{La}$ and $\mathrm{Lc}$ ), the number of polyaromatic layers in the package $(\mathrm{N})$, and the packing density of the lamellae $(\rho)$. It is shown in the work that in vitrinite concentrates, an increase in all analyzed structural parameters ( $\mathrm{Lc}, \mathrm{La}, \mathrm{n}_{\mathrm{atC}}, \mathrm{N}, \rho$ ) is observed with an increase in the degree of metamorphism, at the same time, a decrease in the value of the interplanar distance (d002) is observed. The XRD analysis showed that for the average number of layers in a package and carbon atoms per monolayer, in the samples of vitrinite concentrates of bituminous coals of high stages of metamorphism $\left(\mathrm{R}_{\mathrm{o}, \mathrm{r}}=1.41 \%\right)$ varies from 7 to 8 and $14-15$, respectively. It was found a correlation between the linear nature of the number of polyarene-layers and the height of their stacking. The results obtained were in good agreement with the literature data given for coals of various deposits.
\end{abstract}

\section{References}

[1] O.O. Sanibare, H. Tobias, F. Stephen. Structural characterization of Nigerian coals by X-ray diffraction, Raman and FTIR spectroscopy. Energy. 2010. Vol.35(12). P.5347-5353.

[2] S.A. Sozinov, A.N. Popova, Ch.N. Barnakov, Z.R. Ismagilov. X-ray diffraction technique: structure determination of carbonaceous materials (review). Chemistry for Sustainable Development. 2016. Vol.24. No.4. C.569-576. (russian)

[3] V.I. Saranchuk, A.T. Ayruni, K.E. Kovalev. Supramolecular organization. The structure and properties of coal. Kiev: Naukova Dumka. 1988. 192p.

[4] G.B. Skripchenko. Methodology for studying molecular and supramolecular structures of coals and carbonaceous materials. Solid Fuel Chemistry. 2009. Vol.43. No.6. P.333-340. (russian)

[5] V.I. Kasatochkin. Structural chemistry of coal and carbon. Moscow: Nauka. 1969. 307p. (russian)

[6] L. Lu, V. Sahajwalla, C. Kong, D. Harris. Quantitative X-ray diffraction analysis and its application to various coals. Carbon. 2001. Vol.39. No.12. P.1821-1833.

[7] H. Takagi, K. Maruyama, N. Yoshisawa, Y. Yamada, Y. Sato. XRD analysis of carbon stacking structure in coal during heat treatment. Fuel. 2004. Vol.83. P.2427-2433.

[8] P.N. Kuznetsov, L.I. Kuznetsova, S.M. Kolesnikova, Ya.B. Obukhov. Comparison of the supramolecular organization of brown coals from different deposits. Chemistry for Sustainable Development. 2001. Vol.9. No.5. P.255-261. (russian)

[9] Ch.N. Barnakov, G.P. Khokhlova, A.N. Popova, A.I. Romanenko, Ya.A. Bryatsev. Structure and conductivity of carbon materials produced from coal pitch with carbon additives. Coke and Chemistry. 2017. Vol.60. No.7. P.278-284. (russian)

[10] Ch.N. Barnakov, V.Yu. Malysheva, , Popova A.N., G.P. Khokhlova. Evaluation of the relationship between the structure of graphite-like materials using XRD data and the electrophysical properties of graphite materials - anodes for LIB. Vestn. Kuzbasskogo Gos. Tekh. Univ. 2013. No.5. P.70-73. (russian)

[11] S.A. Sozinov, L.V. Sotnikova, A.N. Popova, and R.P. Kolmikov. Study of the film of $n$-hexane insoluble asphaltene produced from coal-tar pitch. Butlerov Communications. 2017. Vol.51. No.7. P.7580. DOI: $10.37952 /$ ROI-jbc-01/17-51-7-75 
[12] A.N. Popova. The method of calculation of crystallographic characteristics of graphite. Butlerov Communications. 2017. Vol.51. No.7. P.86-90. DOI: 10.37952/ROI-jbc-01/17-51-7-86

[13] G.P. Khokhlova, Ch.N. Barnakov, A.N. Popova. Carbonization of coal pitch with graphite additives. Coke and Chemistry. 2016. Vol.59. No.1. P.27-34. (russian)

[14] Ch.N. Barnakov, G.P. Khokhlova, A.N. Popova, S.A. Sozinov, Z.R. Ismagilov. XRD characterization of the structure of graphites and carbon materials obtained by the low-temperature graphitization of coal tar pitch. Eurasian Chemico-Technological Journal. 2015. Vol.17. No.2. P.87-93.

[15] A.N. Popova, Ch.N. Barnakov, G.P. Khohlova. The study of the structural characteristics of carbon Materials by mean of XRD analysis. Butlerov Communications. 2018. Vol.56. No.11. P.153-159. DOI: 10.37952/ROI-jbc-01/18-56-11-153

[16] G.P. Khokhlova, N. Barnakov, V.Y. Malysheva, A.N. Popova, Z.R. Ismagilov. Effect of heat treatment conditions on the catalytic graphitization of coal-tar pitch. Solid Fuel Chemistry. 2015. Vol. 49. No.2. P.6672. (russian)

[17] G.P. Khokhlova, V.Y. Malysheva, Ch.N. Barnakov, A.N. Popova, Z.R. Ismagilov. Influence of the nature and quantity of catalyst on the phase structure of the carbon material obtained by lowtemperature catalytic graphitization of coal tar pitch Vestn. Kuzbasskogo Gos. Tekh. Univ. 2013. No.5. P.21-24. (russian)

[18] G.P. Khokhlova, Ch.N. Barnakov, A.N. Popova, L.M. Khitsova Influence of carbon additives on the thermal transformation of coal pitch. Coke and Chemistry. 2015. Vol.58. No.7. P.268-274. (russian)

[19] N.I. Fedorova, S.A. Semenova, Z.R. Ismagilov. Material composition of fractions with different densities separated from slurry coal. Solid Fuel Chemistry. 2013. Vol.47. No.4. P.243-248. (russian)

[20] ICDD, PDF-2 (Database), edited by Dr. Surya Kalakkodu. International Centre for Diffraction Data. Newtown Square, PA, USA. 2011.

[21] A.N. Popova. Crystallographic analysis of graphite by X-Ray diffraction. Coke and Chemistry. 2017. Vol.60. No.9. P.361-365. (russian)

[22] C.N. Barnakov, G.P. Khokhlova, V.Y. Malysheva, A.N. Popova, Z.R. Ismagilov. X-ray diffraction analysis of the crystal structures of different graphites. Solid Fuel Chemistry. 2015. Vol.49. No.1. P.2529. (russian)

[23] K.S. Binoy, R.K. Boruah, P.K. Gogoi. X-ray diffraction analysis on graphene layers of Assam coal. J.Chem.Sci. 2009. Vol.1. P.103-106.

[24] J.H. Wang, J. Du, L.P. Chang, K.C. Xie. Study on the structure and pyrolysis characteristics of Chinese western coals. Fuel Processing Technology. 2010. Vol.91(4). P.430-433.

[25] A.N. Popova, N.I. Fedorova, Z.R. Ismagilov. X-Ray Structural Analysis of Vitrinites in Coal at Different Metamorphic Stages. Coke and Chemistry. 2020. Vol.63. No.2. P.57-62. (russian)

[26] A.N. Popova, and S.A. Sozinov. Study of coke microstructure by combination of XRD analysis and SEM. Butlerov Communications. 2018. Vol.56. No.11. P.82-89. DOI: 10.37952/ROI-jbc-01/18-56-11-82 